\title{
Ignoring God Triune? The Doctrine of the Trinity in Dutch Theology
}

\author{
GIJSBERT VAN DEN BRINK AND STEPHAN VAN ERP*
}

\begin{abstract}
This article presents an overview of Dutch trinitarian theology in the twentieth and twenty-first centuries. It will become clear how and why leading Dutch theologians either ignored the doctrine, or used it for their own purposes, or uttered critical reservations regarding its sense and significance. After having reviewed the ways in which this majority of Dutch theologians has dealt with the doctrine, some notable constructive exceptions are explored. In conclusion, the authors raise the question as to Low Dutch theology might, starting from its own tradition, catch up with the recent international and inter-denominational tendency towards a well-developed trinitarian theology.
\end{abstract}

Up to the present, the recent revival of trinitarian thinking has hardly affected Dutch theology. ${ }^{1}$ In fact, it was noticed and charted in the literature only recently. ${ }^{2}$ The current neglect of the Trinity in Dutch theology, however, is not a new development. Apart from some important historical work, ${ }^{3}$ not a single monograph on the doctrine

* Faculty of Theology, VU University, De Boelelaan 1105, 1081 HV Amsterdam, Netherlands and Faculty of Theology, Radboud University Nijmegen, PO Box 9103, Nijmegen 6500 HD, Netherlands.

1 For surveys of this 'revival', see Christoph Schwöbel, 'The Renaissance of Trinitarian Theology: Reasons, Problems and Tasks', in Christoph Schwöbel, ed., Trinitarian Theology Today (Edinburgh: T. \& T. Clark, 1995), pp. 1-30; Stanley J. Grenz, Rediscovering the Triune God: The Trinity in Contemporary Theology (Minneapolis, MN: Augsburg Fortress, 2004). Cf. for a global synopsis Veli-Matti Kärkkäinen, The Trinity: Global Perspectives (Louisville, KY: WJK Press, 2007), esp. pp. 67-380. See also the two collections of essays in honour of Jürgen Moltmann's 80th birthday: M. Volf and M. Welker, eds., God's Life in the Trinity (Minneapolis, MN: Augsburg Fortress Press, 2006); M. Welker and M. Volf, eds., Der lebendige Gott als Trinität (Gütersloh: Gütersloher Verlagshaus, 2006).

2 Gijsbert van den Brink, 'De hedendaagse renaissance van de triniteitsleer. Een oriënterend overzicht' [The Contemporary Renaissance of the Doctrine of the Trinity. A Survey], Theologia Reformata 46 (2003), pp. 210-40.

3 Above all, three recent $\mathrm{PhD}$ dissertations should be mentioned here (in the Netherlands $\mathrm{PhD}$ dissertations in the humanities are often published as soon as they have passed 
of the Trinity and its ramifications has been published in Dutch Protestant theology during the past century. ${ }^{4}$ In Dutch Roman Catholic theology, only Herwi Rikhof has paid explicit attention to the doctrine of the Trinity. ${ }^{5}$ This theological neglect signifies that this doctrine is of little influence not only in modern Dutch theology, but also in ecclesial discussions and in the lives and faith practices of most everyday believers in the Netherlands.

In this article we will try to establish that this situation can be explained by the fact that leading Dutch theologians either ignored the doctrine, or used it for their own purposes, or uttered critical reservations regarding its sense and significance. After having reviewed the ways in which this majority of Dutch theologians has dealt with the doctrine, we will look at some notable constructive exceptions. Finally, we will consider the question as to how Dutch theology might, starting from its own tradition, catch up with the recent international and inter-denominational tendency towards a well-developed trinitarian theology.

In our discussion we intentionally bypass the confessional dividing lines between Roman Catholic and Protestant theology, because it seems to us that the distinction between critical, ambivalent and constructive approaches, which crosses the traditional borderlines, is much more to the point. ${ }^{6}$ Critical approaches range from sceptical to dismissive attitudes towards the doctrine. By 'ambivalent' we mean that at least some lip service is being paid to (the intentions of) the traditional doctrine, but at the same time a lot of embarrassment is felt as to how to actualize it. As a result, the doctrine is either given some new twist, or it is attempted to 'rescue'

examination): Nico den Bok, Communicating the Most High: A Systematic Study of Person and Trinity in the Theology of Richard St Victor (Turnhout: Brepols, 1996); Arie Baars, Om Gods verhevenheid en Zijn nabijheid: De Drie-eenheid bij Calvijn [Concerning God's Highness and Nearness: Calvin on the Trinity] (Kampen: Kok, 2004), a study of 700 pages which meticulously scrutinizes and contextualizes everything that John Calvin has written on the Trinity - an English translation of this work, which may be the most thorough-going inquiry into Calvin's doctrine of the Trinity worldwide, is in process; Alco Meesters, God in drie woorden: Een systematisch-theologisch onderzoek naar de Cappadocische bijdrage aan het denken over God Drie-enig [God in Three Words: A Systematic-Theological Inquiry into the Cappadocian Contribution to Reflection on the Triune God] (Zoetermeer: Boekencentrum, 2006).

4 A study of the patristic scholar Eginhard Meijering, God-Christus - Heilige Geest: Achtergrond en bedoeling van de leer van de drieëenheid [God - Christ - Holy Spirit: Background and Purpose of the Doctrine of the Trinity] (Amsterdam: Balans, 2002), offers, in fact, a summary of the theological and christological ideas of Justin Martyr, Irenaeus, Origen and Athanasius.

5 H. Rikhof, Die in ons wonen. Spiritualiteit, liturgie en theologie [Those who live in us], (Tielt: Lannoo, 2003).

6 Cf. John Webster, 'Discovering Dogmatics', in Darren C. Marks, ed., Shaping a Theological Mind: Theological Context and Methodology (Aldershot: Ashgate, 2002), p. 131: '[I]t slowly dawned on me that the critical divergences are not those between Roman Catholic and Protestant, but the divergence between those who think that the classical exegetical and dogmatic tasks of theology are no longer viable ... and those who are unpersuaded of the need to abandon those tasks'. 
it by dropping constitutive parts of it. By 'constructive' we mean that the inner resources of the Christian trinitarian tradition are rediscovered and revitalized by using it for making constructive proposals that help us to face contemporary challenges.

\section{Critical approaches}

\section{Negligence: G.C. Berkouwer}

A clear example of an influential Dutch Protestant theologian who largely ignored the doctrine of the Trinity and issues related to it is Gerrit Cornelis Berkouwer (1903-96), who taught dogmatic theology at the VU University of Amsterdam. ${ }^{7}$ Berkouwer started his work as an orthodox Reformed theologian, but later became more open to contemporary developments in theology and culture. He is especially well known for his series of 'Studies in Dogmatics', a collection of eighteen volumes discussing classical loci of theology. Looking at the themes of these volumes (revelation, Holy Scripture, divine providence, election, anthropology, sin, Christ, the church, the sacraments, justification, sanctification, perserveration and the parousia), ${ }^{8}$ it is striking that some other loci are conspicuous by their absence - among which figure the doctrine of the Trinity as well as adjacent themes such as the doctrine of God (more broadly speaking) and pneumatology. The subject index of these volumes specify only five places where Berkouwer mentions the Trinity, and one where he briefly discusses the trinitarian grounding of the political state. ${ }^{9}$ In his other works also, ${ }^{10}$ the doctrine of the Trinity is given only scant attention.

An exception can be found in the final pages of a survey of theological developments between 1920 and 1970 that Berkouwer wrote shortly after his retirement. Here he signals that, like Christology, 'the doctrine of the trinity has also met with fresh approaches' during recent years. ${ }^{11}$ Nevertheless, rather than an exploration of these approaches, Berkouwer offers a fairly traditional discussion of

7 Another influential Dutch theologian in whose work we find only few references to the doctrine of the Trinity is Kornelis Heiko Miskotte, who held the Leiden chair of dogmatics from 1945 to 1959.

8 All of these volumes have been translated into English; they were published by an American publisher with Dutch roots, William B. Eerdmans, Grand Rapids, between 1952 and 1976.

9 M.P. van der Marel, Registers op de Dogmatische Studiën van Dr. G.C. Berkouwer (Kampen: Kok, 1988), p. 61 (the subject index comprises pp. 27-67).

10 An almost comprehensive bilingual bibliography has been published by Dirk van Keulen, Bibliografie/Bibliography G.C. Berkouwer (Kampen: Kok, 2000).

11 G.C. Berkouwer, A Half Century of Theology, ed. Lewis B. Smedes (Grand Rapids: Eerdmans, 1977), p. 258; Berkouwer's discussion of the doctrine comprises pp. 258-62. Incidentally, the original Dutch text is twice as long here: Een halve eeuw theologie (Kampen: Kok, 1974), pp. 377-86. 
the trinitarian vocabulary and very briefly tries to connect this to 'the life of the average congregation'. ${ }^{12}$ He does so by concentrating on the economic Trinity, since it is this concept that relates the doctrine of the Trinity to the reality of salvation as it is experienced by faith. In this connection, Berkouwer sides with Rahner and others who pointed to the dangers of modalism and of discussing the Trinity only after the treatise De Deo uno in the doctrine of God. ${ }^{13}$ It is telling, however, that Berkouwer takes the critical approach of Hendrikus Berkhof (that we will discuss below) under his protection, defending it against some charges. On the other hand, when on the same page he quotes the clear and unambiguous judgement of his famous predecessor Herman Bavinck (1854-1921) - 'With the Trinity, far from its being a metaphysical concept or a philosophical speculation, we are at the heart and essence of the Christian religion' - he seems to hesitate. ${ }^{14}$ And understandably so, for if Berkouwer had fully agreed with Bavinck, it would have been all the more strange that he had been so silent about the doctrine. Perhaps, to subsume Berkouwer under 'critical approaches' might be slightly unfair; nevertheless, his reticence to discuss it in his dogmatic work has no doubt paved the way for the much more critical approaches of others, such as his pupil H.M. Kuitert (see below).

\section{Substitution: H. Berkhof}

Whereas Berkouwer was reticent with regard to the doctrine of the Trinity, other leading voices were very critical, if not totally dismissive, both of the doctrine of the Trinity and of doing theology in a trinitarian way. An example of the former is Hendrikus Berkhof (1914-95), who was a professor of dogmatic and biblical theology at Leiden University. Apart from exerting great influence on Dutch pastors and laypersons, especially in middle-of-the-road sections of the church, ${ }^{15}$ Berkhof also had a wide international audience, partly as a result of his participation in the Central Committee of the World Council of Churches for many years (1954-74). Being a prolific author, several of his books have been translated into English; at least one of these (Christ and the Powers) was widely appreciated and is still sometimes

12 Berkouwer, A Half Century of Theology, p. 261.

13 Berkouwer, Een halve eeuw theologie, pp. 381-5.

14 Berkouwer, A Half Century of Theology, pp. 261-2. The quotation of Bavinck is from Bavinck's Gereformeerde Dogmatiek II, fourth edn (Kampen: Kok, 1928), p. 301. Bavinck devoted much more attention to the doctrine of the Trinity than Berkouwer (the discussion in his dogmatics comprises 75 pages); moreover, he had already introduced it as the regulative principle of his prolegomena, where he distinguishes between God as the principium essendi of theology, the Word of God as theology's principium cognoscendi externum and the Spirit of God as its principium cognoscendi internum; see Bavinck, Gereformeerde Dogmatiek I, fourth edn (Kampen: Kok, 1928), pp. 185-6, 253-4.

15 Berkhof coined the awkward term 'middle-orthodoxy' (midden-orthodoxie) as an indication for the large part of the church which is neither liberal nor traditionally orthodox. 
referred to in current Anglo-American theological literature. ${ }^{16}$ Berkhof became most renowned, however, for what is generally considered as his main work: his design of a contemporary systematic theology, entitled Christian Faith, in which many threads that run through his previous books are drawn together and new insights are developed. It is on this masterpiece of doctrinal theology, which is still obligatory reading in many Dutch academic theological training institutes, that we will concentrate here. ${ }^{17}$

The Dutch original of Christian Faith counts seven subsequent editions, dating from 1973 to $1993 .{ }^{18}$ In most of the later editions Berkhof introduced a number of changes which he considered as improvements of the text. Sometimes these changes were of little importance, but at other times they were more substantial. The fifth edition of 1985 in particular contains quite a lot of far-reaching revisions of the text. In relation to this fifth edition, the sixth and seventh editions display only a limited number of minor alterations. In English, there are two translations available, one of the fourth Dutch edition, the other, fortunately, of the fifth one. ${ }^{19}$

As to Berkhof's treatments of the doctrine of the Trinity, there are hardly any differences between the fifth and earlier editions of his book. It seems that the most important decisions were made in the year before the appearance of the first edition of his magnum opus. In a later autobiographical piece he writes:

When it [the manuscript] was finished under the title Christian Faith on 1 January 1973, it occurred to me that the basic lines which I had gradually discovered were not clearly carried through in the first part of the book. Therefore, I started to rewrite that part, and even had to change the entire section on the Trinity, and to replace it from the doctrine of God to the end of Christology. ${ }^{20}$

16 See e.g. Hendrikus Berkhof, Christ and the Powers, trans. and ed. John Howard Yoder (Scottdale, PA: Herald Press, 1962); The Doctrine of the Holy Spirit (Richmond, VA: John Knox Press, 1964); Christ the Meaning of History (Richmond, VA: John Knox Press, 1966; repr. Eugene, OR: Wipf \& Stock Publishers, 2004); Well-Founded Hope (Richmond, VA: John Knox Press, 1969); Introduction to the Study of Dogmatics (Grand Rapids: Eerdmans, 1985); Two Hundred Years of Theology: Report of a Personal Journey (Grand Rapids: Eerdmans, 1989).

17 Berkhof offered some earlier reflections on the doctrine of the Trinity in the final chapter of The Doctrine of the Holy Spirit.

18 H. Berkhof, Christelijk geloof: Een inleiding tot de geloofsleer (Nijkerk: Callenbach, 1973; seventh edn 1993; later editions are unaltered reprints of the 1993 text).

19 Hendrikus Berkhof, Christian Faith: An Introduction to the Study of the Faith, trans. Sierd Woudstra (Grand Rapids: Eerdmans, 1979; rev. edn 1986). A reprint of the revised edition was published in 1999 by Wipf \& Stock Publishers. In the present article, quotations are from the revised edition.

20 H. Berkhof, 'Om de waarheid en om de kerk. Een theologische autobiografie', in Bruggen en bruggenhoofden (Nijkerk: Callenbach, 1981), p. 19, authors' translation. 
We can only conjecture what the contours of Berkhof's first draft on the Trinity were, but it seems clear that his decision to rework and replace it was an incisive one. Indeed, we do not find a single reference to the Trinity in Berkhof's doctrine of God (not even in his prolegomena, as in the Church Dogmatics of Berkhof's admired teacher Karl Barth). Instead, the doctrine of God is composed around the classical themes of the being and attributes of God, and is especially focused on God's 'holy love'. Thus, by removing his treatment of the Trinity from the doctrine of God, Berkhof leaves us with a unitarian view of God.

The reason for this becomes clear when we read the final section of Berkhof's Christology. Berkhof starts this section by saying: "As the creator of the world, as the establisher of the covenant, and as the one who reveals himself to us, we know him as the one God, as a person.' And, 'from this knowledge there is no way toward a doctrine of God as triune'. ${ }^{21}$ But then isn't there such a way from the New Testament narratives on the Father, Christ and the Spirit either? No, because according to Berkhof the New Testament does not depict Christ as the incarnation of God, but as the representative of human beings. Although, especially in the later editions of his work, Berkhof wrestled to make as much as possible of the special character and even uniqueness of Christ's humanity, he remained true to his basic conviction that Jesus Christ does not share the divine nature in any ontological sense. Rather, Christ is the true partner of the covenant, who in the power of the Spirit fulfilled this covenant on behalf of God as our human representative and precursor.

Clearly, if Christ does not in an ontological sense belong to the divine being, the classical doctrine of God as 'three persons in one essence' is misguided. According to Berkhof, this doctrine has 'saddled us with problems that are foreign to Scripture and indigestible to the believing mind' ${ }^{22}$ In this connection Berkhof also points to the lamentable vicissitudes of the doctrine in the course of history: the immanent Trinity (or in Berkhof's phrase: the Trinity of essence) was soon disconnected from the economic Trinity. As a result, the doctrine became a speculative theory about the way in which God's inner being is 'structured', and its place in the doctrine of God, usually after the discussion of the divine being and attributes, turned it into a relatively unimportant and unrelated appendix which hardly plays a role in the practical life of faith. Whereas this observation led Karl Rahner and others to an attempt at revitalizing the doctrine (by returning to its original intent), Berkhof would rather leave this as it is.

Surprisingly however, this does not entail that Berkhof has no room for a doctrine of the Trinity at all. For at the end of his Christology (which includes a short pneumatology), the concept of the Trinity forces itself upon the reader in a spontaneous and positive way. In Berkhof's exposition of the work of Christ and the Spirit it had become clear how the entire Christian faith hinges upon the 'the creation

21 Berkhof, Christian Faith, p. 335.

22 Berkhof, Christian Faith, p. 335; cf. p. 336: 'a difficult problem, an impenetrable mystery, an intellectual crux, and a cause of age-long conflicts and schisms'. 
of the new man, the true Son' as the supreme act of God as Spirit. ${ }^{23}$ So the combination of the three names Father-Spirit-Son turns out to be the 'summarizing description of the covenantal event' ${ }^{24}$ Apart from a historical side this event also has an existential side. By his perfect love and obedience the Son opens the way for the Spirit to unite us with the Son and thereby with the Father. In other words: rather than describing the structure of God, the doctrine of the Trinity describes the structure of the covenant - a covenant which includes the divine Father, humanity as represented by the Son, and the Spirit which is (and clearly here Berkhof draws upon the Augustinian and subsequent Western impersonal view of the Spirit) the bond between them. So 'with the term Trinity we point to a continuing and open event, directed to man'. ${ }^{25}$

Whether one agrees with him or not, Berkhof's attempt to re-think the Trinity in terms of an event rather than a being is certainly original and audacious. But is it still a Christian view of the Trinity? Clearly in order to warrant this, Berkhof makes two additional qualifications. First, the open character of the trinitarian event does not imply that we should talk of a 'multi-unity' (comprising human beings alongside with God) rather than a tri-unity. With laudable precision Berkhof writes: 'The reason that we keep using the term Trinity ... is that even the most intimate human relationship with it still presupposes the distance in essence with respect to God and his Spirit, and the distance as to origin with respect to the "only begotten Son".${ }^{26}$ And second, in calling the Trinity an 'event' Berkhof does not want to ascribe to it any contingency; for this event (and here we hear Barthian overtones) 'is grounded in God's eternal determination to be a God of salvation, a determination which belongs to his very nature'. ${ }^{27}$ In this way, the Trinity is natural and even essential for God.

To our mind, it is hard to see how this can be true. Is not a determination of God, however eternal it may be, by definition a free act of God's will rather than belonging to God's essence? But let us suppose that Berkhof is somehow able to defend his case here. Then it seems that his description of the Trinity as God-in-action-for-us perfectly mirrors what is usually called the economic Trinity. In contemporary trinitarian theology however, it is usually acknowledged that this economic Trinity somehow needs the concept of an immanent Trinity as its counterpart in order to anchor God's trinitarian-action-for-our-salvation in God's very being and to prevent it from dissolving in the contingencies of history. ${ }^{28}$ So this concept does precisely what Berkhof tries to do in a less convincing way, namely, by relating the economic Trinity to God's eternal determination. In the end then, the distance between Berkhof

23 Berkhof, Christian Faith, p. 335; note the phraseology here, which has an Arian flavour (and intentionally so).

24 Berkhof, Christian Faith, p. 335.

25 Berkhof, Christian Faith, p. 336.

26 Berkhof, Christian Faith, p. 336.

27 Berkhof, Christian Faith, p. 337 (translation slightly adapted).

28 For another, even stronger interpretation of the notion of the immanent Trinity, see Paul D. Molnar, Divine Freedom and the Doctrine of the Immanent Trinity (London: T. \& T. Clark International, 2002). 
and trinitarian theology may be smaller than it seems. If Berkhof had drawn the appropriate conclusions from the two qualifications of his view that we described, then he would have had far less reason to reject the traditional conceptuality. In fact, it is mainly his low Christology that prevents him from using the traditional trinitarian categories. Had Berkhof realized and conceded this, then presumably he would have been less critical towards the classical doctrine and towards contemporary attempts to revitalize it. (Having in mind the trinitarian character of both Moltmann's and Pannenberg's theological schemes, Berkhof is reported to have once mockingly described the contemporary trinitarian renaissance as 'the SouthernGerman disease'.)

However, in Berkhof's doctrine of the Trinity the qualifications remained just that: (minor) qualifications. It has been Berkhof's harsh criticism of the tradition together with his substitution of trinitarian doctrine by his own revisional proposal the Trinity as an event rather than a being - that has set the tone and presumably co-determined the continuing trinitarian oblivion in Dutch Protestant theology.

\section{Rejection: H.M. Kuitert}

This picture becomes even more complete and convincing when we look at the contribution of H.M. Kuitert - the enfant terrible of recent Dutch Protestantism. Kuitert is without doubt the most well-known living theologian among Dutch lay people, both believers and non-believers. In his publications on highly contested ethical themes (such as euthanasia and suicide) as well as in his many dogmatic studies a gradual development can be traced, from a more or less orthodox Reformed perspective towards a post-Christian and even post-theistic position. ${ }^{29}$ In order to review his thoughts on the Trinity, we have to turn to the bestseller in which he presents his overall view of the content and meaning of Christian faith, a book he entitled The Generally Doubted Christian Faith: A Revision. ${ }^{30}$ Given the ongoing development of Kuitert's thinking, it should be realized that this book does not state his views in general, but only his views at that moment. Nevertheless, like many of his other publications this book has been very influential, especially among those who are of the same generation as Kuitert - people who are now in their seventies or eighties, and who often found themselves wrestling with the heritage of their strong and over-confident religious upbringing.

29 The title of Kuitert's latest doctrinal monograph is indicative here: Voor een tijd een plaats van god. Een karakteristiek van de mens [Temporarily a Place of God. A Characteristic of Human Beings] (Baarn: Ten Have, 2002); here, Kuitert describes God as a human creation rather than the other way round.

30 H.M. Kuitert, Het algemeen betwijfeld christelijk geloof. Een herziening (Baarn: Ten Have, 1992); the title forms a cynical allusion to a standard introduction of the reading of the Creed in many Protestant church services: 'Let us now confess our general [or catholic] undoubted Christian faith'. The English translation of the book has been given a completely different title: I Have My Doubts: How to Become A Christian without Being a Fundamentalist (London: SCM Press, 1993). 
In his survey of Christian dogmatics, like Berkhof (and most probably influenced by him) Kuitert discusses the doctrine of the Trinity in the final part of his Christology. He only needs a very short introduction of the classical doctrine before giving his judgement: the traditional view of God as triune is "not understood, incomprehensible and unimaginable'. People have to study theology for years 'to be able to understand the ins and outs of the matter'. Of course, we might worship the Trinity without understanding what the Trinity is, as the Eastern Church does. Or we might, following Augustine, speak about God as one being in three persons not in order to say something, but in order not to be completely silent. However, we Westerners want doctrine, and doctrines are intended to offer some degree of understanding. That, however, is something the idea of one substance and three persons falls short of. Moreover, both Muslims and Jews can only see the doctrine as a sign that Christianity worships three Gods rather than one. All in all, the doctrine is 'an occasion for fundamental misunderstandings about the Christian faith'. ${ }^{31}$

In this way Kuitert echoes Berkhof's criticism. However, rather than substituting the doctrine of the Trinity by an alternative conception, as we saw Berkhof doing, Kuitert leaves it at that. He finishes his section on the Trinity with short discussions of the way in which Jesus is related to God (a theme which he would develop more extensively in his next book $)^{32}$ and of the work of the Spirit, who is 'Jesus Christ as we encounter him . . . in the proclamation of the gospel'. ${ }^{33}$ There is no further attempt to explain how these three (if it is three . . . ) belong together or are mutually related to each other. So in fact the problems the trinitarian dogma was intended to answer are left unsolved by Kuitert, and he leaves us with what amounts to a total dismissal of the classical doctrine.

\section{Ambivalent approaches}

\section{Instrumentalization: A.A. van Ruler}

An example of an influential Dutch theologian who hardly showed an interest in the doctrine of the Trinity as such, but who nevertheless used it for his own purposes, is Arnold Albert van Ruler (1908-70). Like Berkouwer, Van Ruler belongs to the Dutch theologians who have gained some reputation in the English-speaking world,

31 Kuitert, I Have My Doubts, pp. 166-8 (the final quotation on p. 168; cf. p. 166: 'a wealth of possible misunderstandings and incomprehension').

32 H.M. Kuitert, Jesus: The Legacy of Christianity (London: SCM Press, 1999). Kuitert's simple (not to say simplistic) argument here is, in brief, that since Jesus was a pious Jew, and pious Jews did not consider themselves to be the Son of God in any unique sense, Jesus did not believe himself to be the Son of God - and therefore neither should we. Jesus's only role was to make the God of Israel available to the whole world. For a critical review, see Expository Times 111 (2000), pp. 397-8.

33 Kuitert, I Have My Doubts, p. 171. 
especially in the USA. A small part of his work has been translated into English. ${ }^{34}$ In the Netherlands, together with K.H. Miskotte and O. Noordmans (see below), Van Ruler is generally regarded as one of the 'great three' twentieth-century theologians of the mainline Protestant church (the former Netherlands Reformed Church). A project which aims at the publication of an annotated edition of his collected works started in 2005 , and is due to comprise at least ten volumes of approximately 500 pages each. ${ }^{35}$ Van Ruler's theology is often labelled 'trinitarian', an indication that goes back to his own work: 'Theology must neither be christological nor pneumatological. These are only parts. In its total reach it can only be described as trinitarian theology . . . ${ }^{36}$

If we look closely at what Van Ruler means by this theological label however, it soon becomes clear that the doctrine of the Trinity predominantly serves as an important methodological tool in his theology. Van Ruler was highly opposed to all kinds of monistic thinking. In particular, underneath the surface of many of his publications there is a hardly concealed polemic against Barthian 'christomonism'. Rather than concentrating on criticism and polemics however, Van Ruler intentionally elaborated a constructive theology of his own that was characterized by 'trinitarian spreading'. As a result, a phrase like 'not only . . but also' is typical for Van Ruler's writings. In theology, we not only have to reflect upon the work of Christ, but also have to take seriously the work of the Spirit - and there are 'structural differences' between the two. In Christology, it is Christ who does everything for us (Van Ruler adhered to a classical view of atonement as penal substitution), whereas in pneumatology we are co-workers with God. However, Van Ruler stresses that the Bible is not only about salvation, but also (and even more fundamentally so) about creation. Creation and history, in turn, should not only be understood as entities in their own right, but also (and mainly) 'out of the end': that is, from the perspective of the eschatological kingdom which is God's ultimate goal. ${ }^{37}$ In this eschatological kingdom human beings will not be 'absorbed' into the trinitarian life of God, but will continue to have a relatively independent existence over against God. So also right now, in theology we not only have to do with God, but also with human beings who

34 See esp. A.A. van Ruler, Calvinist Trinitarianism and Theocentric Politics: Essays towards a Public Theology, trans. John Bolt (Lewiston: Edwin Mellen Press, 1989); apart from an introduction by the translator/editor, this volume contains eight essays characteristic of Van Ruler's theology. See also A.A. van Ruler, The Christian Church and the Old Testament, trans. Geoffrey W. Bromiley (Grand Rapids: Eerdmans, 1971).

35 This series - Verzameld Werk, as distinct from Theologisch Werk, i.e. the much more limited five-volume collection of essays Van Ruler himself started by the end of his life - is edited by Dirk van Keulen. Thus far, volumes 1 and 2 have been published (Zoetermeer: Boekencentrum, 2007 and 2008).

36 A.A. van Ruler, Theologisch Werk V (Nijkerk: Callenbach, 1970), pp. 212-13.

37 Incidentally, these ideas have influenced Jürgen Moltmann, who came into contact with Van Ruler at an early stage of his career. See his lecture at the centenary of the birth of Van Ruler (VU University Amsterdam, December 2008): 'Gestaltwerdung Christi in Kirche und Kultur. Erinnerungen an A.A. Van Ruler', to be published in Gijsbert van der Brink, George Harinck and Dirk van Keulen, eds., Verder met Van Ruler. Over de betekenis van Van Ruler in de $21^{e}$ eeuw (Zoetermeer: Boekencentrum, 2009). 
have their own relative autonomy. So, for example, as Christians, not only do we live in the church, but also in the state.

As Van Ruler makes clear in his essay entitled 'The Necessity of a Trinitarian Theology', these different perspectives should be carefully related to each other. ${ }^{38}$ Just like the divine persons in the Trinity, they should neither be identified or conflated with each other, nor treated in isolation from each other. Rather, the divine and the human, revelation and reason, creation (or 'being', as Van Ruler often says) and salvation, Christ and the Spirit, the community and the individual, church and state, should at the same time be related to each other and kept distinct from each other. According to Van Ruler, the immanent Trinity is characterized by this double movement of relation-to-each-other and distinction-from-each-other.

Arguably, one might indeed conceive the thrust of Van Ruler's theological proposal (with its plea for both-relating-to-and-keeping-distinct-from-each-other the work of the Father in creation and the specific roles of the Son and the Spirit in salvation) as a fine example of sound trinitarian thinking. It might even be claimed that the economic Trinity rightly has priority over the immanent Trinity in Van Ruler's thought. All this can hardly conceal, however, that there is only scant attention to the meaning and significance of the doctrine of the Trinity as such. In fact, apart from two sermons we have only one small piece of Van Ruler on this theme - in which he mostly offers a standard recapitulation of the background of the doctrine in its Augustinian variety ${ }^{39}$ Accordingly, in a recent study of Van Ruler's doctrine of ecclesiastical office, Allan Jansen rightly argues that, 'While Van Ruler's theology is resolutely trinitarian $\ldots$, he gives little energy to working out a full theology of the trinity as such' ${ }^{40}$ Therefore, we can conclude that Van Ruler's theology is trinitarian indeed, but only in the sense that he utilized trinitarian doctrine as an important instrument for the development of his own anti-monistic theological agenda. Reflection on the significance, the depths, the explanatory power and possible meanings of the doctrine itself as the core doctrine of Christianity is largely missing in his work.

\section{Integration: E. Schillebeeckx}

In Dutch Roman Catholic theology, the Dominican revisionist theologian Edward Schillebeeckx argues, unexpectedly perhaps, that any Christology should

38 Van Ruler, Calvinist Trinitarianism, pp. 1-26.

39 'De leer van de drieëenheid', in: A.A. van Ruler, Blij zijn als kinderen. Een boek voor volwassenen [Being Happy like Children. A Book for Adults] (Kampen: Kok, 1972), pp. 92-4. It should be added, however, that Van Ruler infers from the doctrine that there is both movement and communion in God, and that these notions ground our human relationality (pp. 93-4). Here, one might see some degree of affinity with what has come to the forefront of theological reflection in the trinitarian renaissance. Van Ruler does not systematically develop these insights, however.

40 Allan Jay Janssen, Kingdom, Office and Church. A Study of A.A. van Ruler's Doctrine of Ecclesiastical Office (Grand Rapids: Eerdmans, 2006), p. 77. 
acknowledge a necessary place for the doctrine of the Trinity, although he confirms that necessity somewhat reluctantly himself. In Jesus: An Experiment in Christology, he states that 'Jesus' life, his cross and resurrection in the power of the Spirit reveal the depth of the Father-Son relationship, and indeed raise the problem of the Trinitarian God. ${ }^{41}$ Therefore, according to Schillebeeckx, on the one hand the christological problem of Jesus' relationship with God the Father raises trinitarian questions, while on the other hand trinitarian language should always start from christological concerns:

[W]e should not interpret Jesus with the Trinity as our starting-point, but vice versa: only if we start with Jesus is God's unity in its fullness (not so much a unitas trinitatis but a trinitas unitatis) to some extent accessible to us. Only in the light of Jesus' life, death and resurrection can we know that the Trinity is the divine mode of God's perfect unity of being. Only on the basis of Jesus of Nazareth, his Abba experience - source and soul of his message, ministry and death - and his resurrection, is it possible to say anything meaningful about Father, Son and Spirit. ${ }^{42}$

For Schillebeeckx, this christological starting point is not as much based on a theological approach as it is on a historical one, because in early Christianity the 'post-biblical' doctrine of the Trinity only served to explicate the mystery of the Christ, in particular his turning toward God being preceded by God turning to him. Schillebeeckx continues: "early Christian tradition calls this self-communication of the Father - ground and source of Jesus' peculiar Abba experience - "the Word". This implies that the Word of God is the undergirding ground of the whole Jesus phenomenon. ${ }^{43}$ For critics of Schillebeeckx's theology, claiming that he develops a natural theology grounded on experience or reason alone, this trinitarian starting point of his Christology is important to take into account, because it entails that Schillebeeckx's Deus humanissimum, the God with a human face who is concerned with humanity and engaging with human history and experience, is only known by the triune and personal divine revelation.

Despite this 'preceding' of the Son's turning to the Father by the Father's turning to the Son, Schillebeeckx stresses that any distinction between an immanent and economic Trinity is meaningless. Instead of thinking the Trinity as three persons, it is only through the personhood of Jesus that we can refer to the Father and the Holy Spirit in an analogous way as persons. Thus, only "Jesus reveals to us "three persons" in God: Father, Jesus Christ, Pneuma. ${ }^{44}$ In short: Jesus' humanity reveals God as triune and only through his humanity can divine revelation be understood as triune. This is not sheer anthropomorphism, Schillebeeckx argues. Jesus' humanity is the ground for our understanding of God, yet it does not constitute God but it confirms

41 E. Schillebeeckx, Jesus: An Experiment in Christology (London: Collins, 1979), p. 641.

42 Schillebeeckx, Jesus, p. 658.

43 Schillebeeckx, Jesus, p. 658.

44 Schillebeeckx, Jesus, p. 660. 
the fullness of God's personal, absolute unity of being. To be sure, Schillebeeckx denies Jesus' anhypostasis: 'this man, Jesus, within the human confines of a (psychologically and ontologically) personal-cum-human mode of being, is identically the Son, that is, the "Second Person" of the Trinitarian plenitude of divine unity, "the Second Person" coming to human self-consciousness and shared humanity in Jesus'. ${ }^{45}$

In his last collection of essays entitled Theological Testament, Schillebeeckx returns more positively and explicitly to the Trinity in a dense but focused chapter on 'The Mystery of God'. The second part of that chapter is completely dedicated to the doctrine of the Trinity, although it is significantly subtitled 'A Diffident Confession'. He starts with saying that he is very reluctant to reflect on the concept of 'three' in triune, especially in connection with the idea of personhood. Yet, Schillebeeckx does acknowledge a close relationship between God the Father and Jesus Christ, who 'with his resurrection passes us the Spirit as eschatological gift, as a gift from the Father and Himself' ${ }^{46}$ For the later Schillebeeckx, the doctrine of the Trinity should not be treated as a separate doctrine, but always as an integral part of the doctrines of creation, Christ, salvation and eschatology. Only from this integrative dogmatic starting point is Schillebeeckx willing to speak explicitly about the Trinity, albeit only at the end of his theological career.

Schillebeeckx insists that one should not talk about three persons in God, but about the triune character of the divine nature. The doctrine of the Trinity serves mainly to understand that divine nature as being personal: 'The Trinity is the specific mode of God's personalist nature. ${ }^{47}$ The unspeakable nature of God as a person is revealed by God himself in, as Schillebeeckx puts it, 'God's eschatological revelation in Jesus, experienced by people, interpreted and testified as the Christ, Son of God. Only since the life of Jesus of Nazareth and only since the recognition of Him as the messianic Son of God do believers have knowledge of the triune structure of God.' So, Schillebeeckx's doctrine of the Trinity is christocentric, because he argues that only through Christ's salvific work has it become clear what God's personhood means for us. His concept of the divine hypostatic nature is relational, yet not intrarelational. In short, Schillebeeckx's doctrine of the Trinity reflects God's personhood in a non-modalistic, but ternary personalist way. Meanwhile, his language is dense; his formulations are very cautious and 'diffident'. It is questionable whether some substantial notion of an immanent Trinity is retained in the end. In any case, the impression that the doctrine of the Trinity is first of all a huge problem is not structurally overcome. All in all, Schillebeeckx's attitude towards the doctrine remains ambivalent.

45 Schillebeeckx, Jesus, p. 667.

46 E. Schillebeeckx, Theologisch Testament. Notarieel nog niet verleden (Baarn: H. Nelissen, 1994), p. 96. Part of this book has been translated under the title I am a Happy Theologian (New York: Crossroad, 1994).

47 Schillebeeckx, Theologisch Testament, p. 96. 


\section{Dialogue: P. Schoonenberg}

Like Schillebeeckx, the Jesuit theologian Piet Schoonenberg has paid explicit attention to the concept of personhood in the doctrine of the Trinity. Schoonenberg could be called 'the forgotten Dutch theologian', because his reputation has always stood in the shadow of Schillebeeckx's. Yet many of his books have been translated into German and English, and his pneumatology and work on the doctrine of sin were very influential in the 1960 s and 1970s. ${ }^{48}$ With Van Ruler and Schillebeeckx, he shares Rahner's adage that the immanent Trinity is the economic Trinity and vice versa. According to Schoonenberg also, a theology of the immanent Trinity is meaningless without taking the history of salvation into account. This does not mean, however, that he dismisses the concept of the immanent Trinity altogether, as Schillebeeckx seems to do. According to Schoonenberg, the immanent Trinity becomes fully interpersonal only after creation and incarnation, which has led critics to argue that he denies God's immutability, because his nature depends on historical events. Schoonenberg, however, responded to his critics that God, instead of being dependent on history, changed himself through revelation in creation and incarnation, thereby showing the priority of the inner-trinitarian life, even though that priority reveals itself to us after the incarnation.

In a posthumously published collection of texts, this debate brings him to reflect on the pre-existence of the personhood of the Son and the Spirit, which he eventually denies. ${ }^{49}$ Son and Spirit can only be called 'personal' in analogy to God's personal relationship with us. Moreover, according to Schoonenberg, this should entail that it is only possible to reflect on the personhood of Son and Spirit after the incarnation, after God has made himself known in the world through Jesus Christ. His concern here is pneumatological. Schoonenberg argues that, in the history of theology, Christology has more and more become a Logos-Christology, based on the Gospel of John. A Spirit-Christology has been theologically underexposed. As a consequence, the Son was viewed as the Second Person of the Trinity, and accordingly, the Spirit as the Third Person. ${ }^{50}$ But how is it then possible, Schoonenberg asks, for Jesus to receive the Spirit if his Sonship is pre-existent? To him, trinitarian reflection is a matter of priority and change. The divine acts of creation and incarnation have priority over the immanent Trinity as being interpersonal. Through creation and

48 P. Schoonenberg, Man and Sin: A Theological View (London: Sheed \& Ward, 1965); P. Schoonenberg, The Christ: A Study of the God-Man Relationship in the Whole of Creation and in Jesus Christ (London: Sheed \& Ward, 1972).

49 P. Schoonenberg, De Geest, het Woord en de Zoon. Theologische overdenkingen over Geest-christologie, Logos-christologie en drieëenheidsleer (Averbode/Kampen: Altiora/Kok, 1991), pp. 160-6. The final part of this book (pp. 207-17) has also been published in English: 'The Doctrine of the Trinity: An Empty Dogma or a Fruitful Theologoumenon?', Louvain Studies 16 (1991), pp. 195-207.

50 Cf. H. Rikhof, 'Over Piet Schoonenberg', in J. Beumer, ed., Zo de ouden zongen ... leraar en leerling zijn in de theologie-beoefening (tussen 1945 en 2000) (Kampen: Ten Have, 1996), pp. 198-220. 
incarnation, God changes and becomes fully interpersonal as Father, Son and Spirit. To this latter idea of change, Schoonenberg adds that the Father's turn to the Christ-event is eternal, and not dependent on the incarnation.

Schoonenberg's reflections on the priority of the immanent Trinity before the incarnation are the consequence of his attempt to advocate a close relationship between a Word-Christology and a Spirit-Christology. It is especially the latter that, according to him, deserves more attention in the future of theology. This is so, not only because the role of the Spirit has been underrated, but also because it is through pneumatology that the doctrines of Christ and salvation can be connected. Schoonenberg argues that Jesus received the Spirit when he was baptized, which is a crucial and fully historical event that is part of his salvific work. The concept of perichoresis gets its full meaning in this Christ-event, because it is only from that moment on that a distinction between the divine hypostases can be made. It is this distinction through which God's Trinity completes the covenant within his own being. ${ }^{51}$ Salvation history is completed through the dialogue between Father and Son, which is mediated by the Spirit-mediator who has made this history the work of an inner-trinitarian trialogue.

Methodically, Schoonenberg's approach can be compared to that of Schillebeeckx and many others. Starting from the modern embarrassment at the traditional terminology ('one being and three persons', and so on), Schoonenberg attempts to go back to the tradition and to grasp the doctrine's original background. Then, the classical conceptuality is reinterpreted and recontextualized from this perspective, but those parts of it which can hardly be made acceptable to the modern mind (such as the pre-existence of the Son and the Spirit) are nevertheless rejected. That is why we classify Schoonenberg's way of proceeding, despite its impressive subtlety and creativity, as an ambivalent approach.

\section{Living voices: A. van de Beek, V. Brümmer and H. Rikhof}

Finally, some thoughtful reflections on the doctrine of the Trinity can be found in the work of three leading present-day theologians: Abraham van de Beek, Vincent Brümmer and Herwi Rikhof. Since all three of them are still in the process of developing their thinking, we cannot give a final evaluation and will therefore be more brief about them. Van de Beek is by far the most prolific Dutch systematic theologian at the moment. Brümmer is a philosopher of religion from South Africa who has been working in the Netherlands for more than four decades now, and whose work inspired a group of younger philosophically-oriented Dutch theologians that came to be known as the 'Utrecht school in philosophical theology'. ${ }^{52}$ Herwi Rikhof

51 Schoonenberg, De Geest, het Woord en de Zoon, p. 174.

52 For a sample of their work, see Gijsbert van den Brink \& Marcel Sarot, eds., Understanding the Attributes of God (Frankfurt: Peter Lang, 1999). 
is a Catholic priest and the systematic theologian of the Catholic canonical faculty of the University of Tilburg, located also in Utrecht, where Rikhof is based.

Van de Beek's theology is characterized by a very strong and sustained christological emphasis. A favourite quotation of his is from the Roman bishop Zephyrinus (in office AD 198/9-217): 'I know only one God, Jesus Christ, and no one else than the One who was born and did suffer. ${ }^{53}$ It is this (some would say: rigid) identification of the true God with the suffering Jesus which makes Van de Beek suspicious of the Cappadocian contribution to the development of trinitarian doctrine:

The formulations of the Cappadocians miss the intensity and the edginess of Athanasius. Christ as the incarnate Word is not tied as closely to the Father ... When I read the writing of the Cappadocians, I enter a world that is very different than $[\mathrm{sic}]$ the world of thought of Athanasius. Here theology has become fashionably elitist and esoteric. ${ }^{54}$

Presumably, Van de Beek will level such allegations (which are, to our mind, unfair) even more forcefully against contemporary social doctrines of the Trinity, especially when these are used to propagate more general contemporary philosophical thought forms, such as the importance of relationality, personhood or equality; but we still have to await the more extensive discussion of the doctrine of the Trinity he has planned for one of the future volumes in his series of dogmatic monographs.

Vincent Brümmer is the only Protestant theologian discussed here whose work shows a clear awareness of the recent trinitarian renaissance. However, his response to this development, and especially to its tendency towards a more 'social' elaboration of the doctrine of the Trinity, is fairly critical. Brümmer uses the concept of what he calls 'biblical monotheism' as an unambiguous yardstick against which to measure both traditional and recent proposals in trinitarian thinking, and this leads him to express a strong preference for Latin trinitarianism with its conception of God as 'a single personal being' ${ }^{55}$ Brümmer creatively defends this view against the well-known charge of modalism, but has to admit that it is difficult to reconcile it with the eternal nature of God's love. So here he retreats into agnosticism. ${ }^{56}$ Meanwhile, his preference for forms of trinitarian thinking that start from a clear conception of the unity of God enables him to provide 'a more satisfactory point of

53 Hippolytus, Refutatio omnium haeresium IX, 11. Cf. Abraham van de Beek, Jesus Kyrios: Christology as Heart of Theology (Zoetermeer: Meinema, 2002), pp. 14-15, 50-1, 74, 76; this book, originally published in Dutch (1998), is the first in a series of dogmatic monographs, the second and third volume of which are dedicated respectively to the place of Israel in Christian theology (2002) and to eschatology (2008).

54 Van de Beek, Jesus Kyrios, p. 75.

55 Vincent Brümmer, Atonement, Christology and the Trinity: Making Sense of Christian Doctrine (Aldershot: Ashgate, 2005), p. 106. A Dutch edition of this book was published simultaneously: Ultiem geluk [Ultimate Happiness] (Kampen: Kok, 2005).

Brümmer, Atonement, pp. 108-12. 
departure for dialogue with Jewish and Moslems' ${ }^{57}$ Or is it, conversely, his wish to reduce the differences between the Abrahamic religions that inspired his preference for Latin trinitarianism in the first place? However this may be, it could be questioned whether 'biblical monotheism' is such a monolithic concept as Brümmer suggests, or that, alternatively, this concept leaves more room for the acknowledgement of plurality in God than we might initially think..$^{58}$

Currently, there is only one Catholic Dutch theologian who has developed a separate trinitarian theology: Herwi Rikhof. In a long theological essay that has similarities to Nicholas Lash's Believing Three Ways in One God, ${ }^{59}$ he connects the doctrine of the Trinity to the main feast days in the liturgical year. ${ }^{60}$ Following the theology of Schoonenberg, Rikhof's trinitarian theology finds its starting point in pneumatology. By focusing on the role of the Spirit and its significance for the practice of faith, he attempts to overcome the criticism that the doctrine of the Trinity is not part of living faith - hence the central attention to prayer and liturgy in his work. Rikhof finds his theological inspiration in the work of Basil of Caesarea, who reflected on the distinct formulas: 'Glory be to the Father and the Son, with the Holy Ghost' and 'glory be to the Father, through the Son, in the Holy Ghost'. Basil opted for the first formula, because it signifies better the dignity of the Holy Spirit. Rikhof follows Basil in this choice and states that the use of this formula in baptism confirms the important meaning of the Trinity for the practice of faith. ${ }^{61}$

\section{Conclusion}

In our opinion, the turn to trinitarianism that has taken place in many different branches of Christian theology since the pivotal work of Karl Barth and Karl Rahner implies a real paradigm shift in the Kuhnian sense of the word. Rather than taking the modern predicament as a starting point in order to examine from that vantage point to what extent the doctrine of the Trinity might hopefully still be saved today, numerous theologians from widely divergent denominational backgrounds (and often independently from one another) started to work the other way round. Their question became: what kind of hidden spiritual and theological resources does the early Christian tradition harbour which modern believers have largely forgotten about? The sheer fecundity of these resources (as they were found, e.g. in the

57 Brümmer, Atonement, p. 118.

58 For an excellent, well-balanced discussion of the way in which the biblical narratives (especially in the Gospels) gave rise to the development of the doctrine of the Trinity, see Mike Higton, Christian Doctrine (London: SCM Press, 2008), pp. 77-105; for the close relationship between Jewish monotheism and the early Christian worship of Jesus, see e.g. Larry W. Hurtado, One God, One Lord (London: SCM Press, 1988).

59 N. Lash, Believing Three Ways in One God (London: SCM Press, 1992).

60 H. Rikhof, Die in ons wonen. Spiritualiteit, liturgie en theologie van God de Drie-ene (Tielt: Lannoo, 2003).

61 Rikhof, Die in ons wonen, p. 15. 
Cappadocians) has only gradually dawned on them, and the process of figuring out the tradition's remaining significance and impact is still unfinished.

Whereas theologians from many Western countries have participated in the shift towards this new paradigm (Colin Gunton and Thomas Torrance in Great Britain, Jürgen Moltmann, Wolfhart Pannenberg, Gisbert Greshake and Christoph Schwöbel in Germany, Elisabeth Johnson, Catherine Mowry LaCugna and Robert Jenson in the USA, Miroslav Volf from Croatia, Leonardo Boff in Latin America, to mention only some of the most well-known names), the Dutch have mainly been conspicuous by their absence until the present day. Above, we have tried to explain this situation by surveying the way in which the most influential recent Dutch theologians have dealt with the doctrine of the Trinity and with the idea of doing theology in a trinitarian way (as far as this idea occurred to them). It turned out that the attitude of most of them was at best reticent (Berkouwer) or ambivalent (Schoonenberg and others), and at worst purely dismissive (Kuitert). Apart from Herwi Rikhof, most systematic theologians who are active in the field today have uttered their reservations.

Is Dutch theology missing the boat? Is there, perhaps, something in the typically Dutch Christian landscape that makes it difficult for Dutch theologians to grasp the new trinitaratian perspective? We do not think this is necessarily the case. For there is one important exception to this general picture which we have not mentioned thus far, but with a reference to whose work we want to finish our explorations. This concerns the Frisian theologian Oepke Noordmans (1871-1955), who was a lifelong minister in a couple of small Dutch villages. There he wrote his theological work, which has recently been collected in a multi-volume annotated edition that comprises thousands of pages. ${ }^{62}$ Noordmans is seen by many as the most genial and original Dutch theologian of the twentieth century, and his prophetic view regarding the pivotal importance of the doctrine of the Trinity suggests that this judgement may be right. Perhaps Noordmans' role can be compared to that of P.T. Forsyth in British theology, especially when it comes to his radically christocentric thinking. Like Forsyth, Noordmans is seen by many as a 'Barthian before Barth', but in both cases it seems that this qualification does insufficient justice to the even more critical nature of their theology.

Noordmans' emphasis on Christology (and, in his case, more specifically on the cross of Christ) did not prevent him from taking the doctrine of the Trinity with utmost seriousness. Clearly, he knew that the church proclaimed this doctrine precisely 'in order to keep its confession of Christ pure'. ${ }^{63}$ In this connection, Noordmans compares the Apostles' Creed with a bird, which can only fly because its weighty body (i.e., Christology) is accompanied by the two wings of the doctrine of

62 O. Noordmans, Verzamelde Werken, 10 vols. (Kampen: Kok, 1978-2004).

63 O. Noordmans, Herschepping [Recreation] (Zeist: NCSV, 1934), p. 16; this 'pastoral dogmatics', which is usually seen as Noordmans' main work in systematic theology, has not been translated into English; nor have any of his many other writings - which is in part owing to the fact that, as a result of Noordmans' aphoristic and often elusive style of writing, it would be a very hard job to translate his work. 
God the Father and of pneumatology. ${ }^{64}$ It is true that God is one; but this unity is 'broken'. 'When speaking to us is not enough, God comes; and when coming is not enough, God comforts us.' In this economy, God reveals Godself as Father, Son and Spirit - in fact, the whole of the Bible is full of this pattern. Therefore, this plurality in God should always be discernible in Christian preaching: 'We aren't Muslims'. ${ }^{65}$ It was especially the Eastern Church, according to Noordmans, which as a result of its philosophical training succeeded in keeping the doctrine of the Trinity free from deterioration. For Western believers it is important to realize that there is no way from the unity of God to the threeness - rather, following the biblical narratives, we should proceed in the reverse order. ${ }^{66}$ Clearly, Noordmans' main interest was in the economic Trinity, that is, in the history of salvation, which he could only interpret in a trinitarian way. ${ }^{67}$ Noordmans even anticipated Rahner's criticism of the traditional concentration on the immanent Trinity, by opposing any speculation about God's inner being that does not have its only criterion in the concrete history of salvation. ${ }^{68}$

So in the end, in the theology of Noordmans - and to a lesser degree also in that of Schoonenberg - we can find some early intimations of the awakening trinitarian consciousness which would considerably change the thrust of Christian theology worldwide. Dutch systematic theologians today who wish to appreciate the importance of the contemporary revival of trinitarian theology can turn to some of their colleagues in the past century in order to come to understand some of its leading motives. Noordmans' and Schoonenberg's greater attention to the Spirit and hence to the living practice of faith would be an appropriate starting point for making a new connection between a theology of the Trinity and contemporary Christian faith in the Netherlands.

64 Noordmans, Herschepping, p. 17.

65 Noordmans, Herschepping, p. 15 (all three quotations). Noordmans subscribed to a regulative view of doctrine (comparable to a large extent to that of George Lindbeck and other post-liberal theologians), according to which (trinitarian) doctrine is a communally authoritative rule that structures and governs Christian speech (rather than being preached itself); cf. Herschepping, pp. 2-10.

66 Noordmans, Herschepping, p. 17; cf. Verzamelde Werken II (Kampen: Kok, 1979), p. 446: 'We cannot start from the one God in order to proceed from there to the three persons. That way does not exist for us. We encounter the three persons in Scripture and in preaching, and the believer professes: this is our God ....

67 Noordmans, Verzamelde Werken II, p. 449: 'In the history of salvation . . . this plurality [in God] breaks open, until it is present in the New Testament on almost every page'.

68 Cf. Berkouwer, Een halve eeuw theologie, pp. 384-5 (in the English translation of these pages, the references to the work of Noordmans are omitted). 